\title{
Parallel variation of mass transport and heterogeneous and homogeneous electron transfer rates in hybrid redox polyether molten salts
}

\author{
Amanda S. Harper-Leatherman \\ Fairfield University, aharper@fairfield.edu \\ Dongil Lee \\ Joseph C. Crooker \\ Hb甲bWams and additional works at: https://digitalcommons.fairfield.edu/chemistry-facultypubs

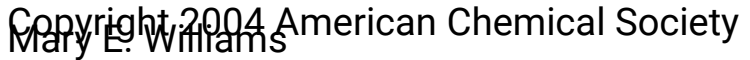 \\ The published article is also available on the journal site: \\ http://pubs.acs.org/doi/abs/10.1021/jp036479\%2B \\ See next page for additional authors \\ Peer Reviewed
}

\section{Repository Citation}

Harper-Leatherman, Amanda S.; Lee, Dongil; Crooker, Joseph C.; Wang, Wei; Williams, Mary E.; and Murray, Royce W., "Parallel variation of mass transport and heterogeneous and homogeneous electron transfer rates in hybrid redox polyether molten salts" (2004). Chemistry \& Biochemistry Faculty Publications. 4. https://digitalcommons.fairfield.edu/chemistry-facultypubs/4

\section{Published Citation}

Harper, Amanda S.; Lee, Dongil; Crooker, Joseph C.; Wang, Wei; Williams, Mary E.; Murray, Royce W. “Parallel variation of mass transport and heterogeneous and homogeneous electron transfer rates in hybrid redox polyether molten salts." Journal of Physical Chemistry B, 2004, 108 (6), 1866-1873.

This item has been accepted for inclusion in DigitalCommons@Fairfield by an authorized administrator of DigitalCommons@Fairfield. It is brought to you by DigitalCommons@Fairfield with permission from the rightsholder(s) and is protected by copyright and/or related rights. You are free to use this item in any way that is permitted by the copyright and related rights legislation that applies to your use. For other uses, you need to obtain permission from the rights-holder(s) directly, unless additional rights are indicated by a Creative Commons license in the record and/or on the work itself. For more information, please contact digitalcommons@fairfield.edu. 
Authors

Amanda S. Harper-Leatherman, Dongil Lee, Joseph C. Crooker, Wei Wang, Mary E. Williams, and Royce W. Murray 


\title{
Parallel Variation of Mass Transport and Heterogeneous and Homogeneous Electron Transfer Rates in Hybrid Redox Polyether Molten Salts
}

\author{
Amanda S. Harper, Dongil Lee, ${ }^{\dagger}$ Joseph C. Crooker, Wei Wang, \\ Mary Elizabeth Williams, ${ }^{*}$ and Royce W. Murray* \\ Kenan Laboratories of Chemistry, University of North Carolina, Chapel Hill, North Carolina 27599
}

Received: August 20, 2003; In Final Form: December 12, 2003

\begin{abstract}
Metal complexes can be prepared as highly viscous (semisolid), room temperature molten salts by combining them with oligomeric polyether substituents. The fluidity and transport properties of these hybrid redox polyether melts can be systematically manipulated by changing the oligomeric chain lengths and by adding unattached oligomers as plasticizers. This paper describes the voltammetrically measured transport properties of several Co(II) polypyridine $\left(2,2^{\prime}\right.$-bipyridine, phenanthroline) melts. The properties evaluated are the physical selfdiffusion coefficient ( $D_{\mathrm{PHYS}}$ ) of the cationic complex in its melt, the diffusivity of its counterion $\left(D_{\mathrm{CION}}\right)$, the heterogeneous electron-transfer rate constant $\left(k_{\mathrm{HET}}\right)$ of the $\mathrm{Co}(\mathrm{III} / \mathrm{II})$ oxidation at the electrode surface, and the rate constant $\left(k_{\mathrm{EX}}\right)$ for homogeneous electron self-exchange between $\mathrm{Co}(\mathrm{II})$ and $\mathrm{Co}(\mathrm{I})$ in the mixed valent layer next to the electrode. These dynamics parameters change in parallel manners, over a large $\left(>10^{3}\right)$ range of values, when the melt fluidity is changed by plasticizers or temperature. While $k_{\mathrm{HET}}$ and $k_{\mathrm{EX}}$ both change systematically with $D_{\mathrm{PHYS}}$, they change on a more nearly proportional basis with $D_{\mathrm{CION}}$. The latter relationship is interpreted as a kind of solvent dynamics control in which both the homogeneous $\mathrm{Co}(\mathrm{II} / \mathrm{I})$ and heterogeneous $\mathrm{Co}(\mathrm{III} / \mathrm{II})$ reaction rates are controlled by the ionic atmosphere relaxation time constant, namely, the time constant of redistribution of counterions following an electron-transfer step that has produced a nonequilibrium charge distribution. $D_{\text {CION }}$ provides a measure of the ion atmosphere relaxation rate.
\end{abstract}

\section{Introduction}

When polyether oligomers are covalently bonded to normally crystalline redox active compounds, or are bonded to their counterions, the result is a highly viscous, amorphous, roomtemperature molten salt or molecular melt. ${ }^{1}$ Such redox polyether hybrid materials, in their neat state, can exhibit large viscosities (as large as $10^{6} \mathrm{cP}$ at $\left.25^{\circ} \mathrm{C}\right)^{1 \mathrm{~h}}$ and are model semisolids. The melts consist of hard cores of redox moieties surrounded by soft, deformable polyether shells. ${ }^{\text {lc }}$ Their viscosities are large because the redox moiety contributes little to the material's free volume, which increases and viscosity decreases as the molar volume fraction of the redox polyether hybrid material that is polyether oligomer increases. ${ }^{\text {1a }}$ The number and length of the oligomer chains determine the latter and greatly affect both mass and charge transport. ${ }^{1 c, 2}$ Added, unattached polyether oligomer also enhances transport properties, as does sorption from a liquid $\mathrm{CO}_{2}$ phase ${ }^{3}$ this is called diffusion plasticization, or just plasticization. ${ }^{4}$

This report describes mass transport and Co(III/II) and Co(II/I) electron-transfer dynamics in a series of molten salts of Co polypyridine metal complexes (structures in Figure 1). Melt I is a Co phenanthroline (phen) complex, in which a MePEG 350 oligomer (methyl-terminated polyethylene glycol, average MW $=350$ ) has been covalently bonded to its sulfonate counterion $\left(\mathrm{MePEG}_{350} \mathrm{SO}_{3}{ }^{-}\right)$. This $\left[\mathrm{Co}(\text { phen })_{3}\right]\left(\mathrm{MePEG}_{350}-\mathrm{SO}_{3}\right)_{2}$ material (I) is plasticized in two ways, by adding unattached, neutral MePEG $_{350}$ oligomer and by adding an ammonium salt of the $\mathrm{MePEG}_{350}$ tailed counterion, $\left(\mathrm{NH}_{4}\right)\left(\mathrm{MePEG}_{350} \mathrm{SO}_{3}\right)$. Melt $\mathbf{I I}_{n}$ in Figure 1 is a bipyridine complex in which the bpy ligands

* Corresponding author. E-mail: rwm@email.unc.edu.

$\dagger$ Present address: Western Michigan University.

$\doteqdot$ Present address: Pennsylvania State University.
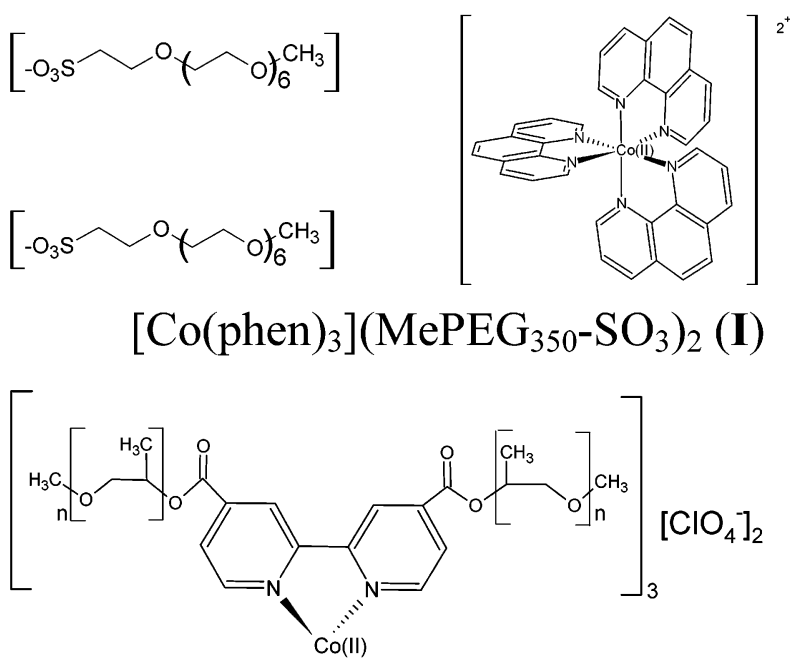

$\left[\mathrm{Co}\left(\operatorname{bpy}\left(\mathrm{P}_{\mathrm{n}} \mathrm{M}\right)_{2}\right)_{3}\right]\left(\mathrm{ClO}_{4}\right)_{2}, \mathrm{n}=1,2,3\left(\mathbf{I I}_{\mathbf{n}}\right)$

Figure 1. Structure of cobalt trisphenanthroline counterion tailed melt ([Co(phen $\left.\left.)_{3}\right]\left(\mathrm{MePEG}_{350} \mathrm{SO}_{3}\right)_{2}\right)$ (I) and of cobalt trisbipyridine perchlorate melt $\left(\left[\mathrm{Co}\left(\mathrm{bpy}\left(\mathrm{P}_{\mathrm{N}} \mathrm{M}\right)_{2}\right)_{3}\right]\left(\mathrm{ClO}_{4}\right)_{2}\right)\left(\mathbf{I I}_{n}\right)$ where $n=2$ or 3 .

bear attached $\left(\mathrm{P}_{n} \mathrm{M}\right)$ methyl-terminated polypropylene oxide oligomers having either 2 or 3 repeat units. ${ }^{2 b}$ These perchlorate complexes $\left(\left[\mathrm{Co}\left(\mathrm{bpy}\left(\mathrm{P}_{n} \mathrm{M}\right)_{2}\right)_{3}\right]\left(\mathrm{ClO}_{4}\right)_{2}\right)$ can exhibit exceptionally low fluidity owing to the small number of propylene oxide repeat units; in practice, the fluidity of a given melt $\mathbf{I I}_{\boldsymbol{n}}$ also varies widely as a result of minor variations in the stoichiometry of the prepared complex (analytically established as having either excess $\mathrm{P}_{3} \mathrm{M}$ or $\mathrm{P}_{2} \mathrm{M}$ ligand or excess Co ions) and by adventitious traces of adsorbed moisture. The $\mathbf{I I}_{\boldsymbol{n}}$ melts do not crystallize owing to the diasteromeric-mixture character of the 
propylene oxide chains; their ethylene oxide analogues slowly crystallize over weeks of standing.

In this study, we describe the electron-transfer rate constants for homogeneous $\mathrm{Co}(\mathrm{II} / \mathrm{I})$ electron self-exchanges $\left(k_{\mathrm{EX}}\right)$ and for heterogeneous $\mathrm{Co}(\mathrm{III} / \mathrm{II})$ electron transfers $\left(k_{\mathrm{HET}}\right)$, and the selfdiffusion coefficients of the Co complexes $\left(D_{\mathrm{PHYS}}\right)$ and of their counterions $\left(D_{\mathrm{CION}}\right)$, in the neat and plasticized melts. Co polypyridine complexes are convenient for this purpose because, as first demonstrated ${ }^{5}$ by Buttry and Anson, the $\mathrm{Co}$ (II) physical diffusion rate ( $D_{\text {PHYS }}$ ) can be measured voltammetrically from oxidation currents of the Co(II) complex. Similarly, the Co(II/ I) electron self-exchange rates can be measured voltammetrically from the enhanced apparent diffusivity $\left(D_{\mathrm{APP}}\right)$ upon reducing the $\mathrm{Co}$ (II) complex. The Co(II) apparent diffusivity is enhanced by the rapid electron hopping within the $\mathrm{Co}(\mathrm{II} / \mathrm{I})$ mixed valent diffusion layer generated around the electrode; the contribution of hopping, or "electron diffusion" $\left(D_{\mathrm{E}}\right)$ to $D_{\mathrm{APP}}$ can be estimated using the cubic lattice model $^{6}$

$$
D_{\mathrm{APP}}=D_{\mathrm{PHYS}}+D_{\mathrm{E}}=D_{\mathrm{PHYS}}+k_{\mathrm{EX}} \delta^{2} C / 6
$$

where $k_{\mathrm{EX}}$ is the homogeneous $\mathrm{Co}(\mathrm{II} / \mathrm{I})$ electron self-exchange rate constant, $\delta$ the equilibrium center-center distance between complexes, ${ }^{7}$ and $C$ the total concentration of cobalt complex sites in the melt.

The Co(III/II) electron self-exchange is quite slow, ${ }^{8 a}$ so the $D_{\text {APP }}$ of Co(II) oxidation measures solely $D_{\text {PHYs. The Co(III/II) }}$ reaction rate $\left(k_{\mathrm{HET}}\right)$ is measured as a heterogeneous reaction since, in the voltammetry, the $\mathrm{Co}$ (III/II) electrode reaction is electrochemically quasireversible. The counterion transport rate $\left(D_{\mathrm{CION}}\right)$ is measured from a combination of $D_{\mathrm{PHYS}}$ and the melt ionic conductivity, using the Nernst-Einstein relation. The $D_{\text {CION }}$ results are supported by direct voltammetry of iodide as a model counterion. By varying the added plasticizers and the melt temperature, a roughly $10^{3}$ range of the above dynamics constants was achieved in melts of $\mathbf{I}$ and $\mathbf{I I}_{\boldsymbol{n}}$.

The motivation of the above measurements is to understand why electron-transfer rates in semisolids such as $\mathbf{I}$ and $\mathbf{I}_{\boldsymbol{n}}$, and in a number of other redox polyether hybrids, are generally slower and exhibit larger thermal activation energy barriers ${ }^{1 b, c, d}$ than predicted by Marcus theory ${ }^{9}$ or observed experimentally for analogous reactions in dilute, low-viscosity fluid solutions. We reported previously that, over a huge $\left(10^{11}\right.$-fold $)$ dynamics range, (a) the $\mathrm{Co}$ (III/II) $k_{\mathrm{HET}}$ varied inversely with the longitudinal relaxation time in a series of Debye solvents ${ }^{10,11}$ and $b$ ) in a series of polyether solutions and redox hybrid melts $k_{\text {HET }}$ varied systematically with $D_{\text {PHYs }}$ of the Co complex. ${ }^{1 e}$ Others ${ }^{12}$ have also seen correlations (albeit over more narrow ranges) between $k_{\text {HET }}$ and physical diffusion rates of metal complexes. These correlations have been interpreted as control of the electron transfer rate by the dynamics of solvent repolarization upon charge transfer. Solvent repolarization rates are presumed to analogously dictate mass transport dynamics. In the case of diffusants such as $\mathbf{I}$ and $\mathbf{I I}_{\boldsymbol{n}}$, the "solvent" is the attached shell of polyether oligomer chains.

Analogous correlations have also been observed for homogeneous $\mathrm{Co}(\mathrm{II} / \mathrm{I}) k_{\mathrm{EX}}$ rate constants. Recent measurements ${ }^{3 \mathrm{~b}}$ in Co complex melts such as $\mathbf{I}$, plasticized by sorption from a liquid $\mathrm{CO}_{2}$ bath, revealed a strong correlation between $k_{\mathrm{EX}}$ and $D_{\mathrm{PHYS}}$ of the complex, suggesting that the $\mathrm{Co}(\mathrm{II} / \mathrm{I})$ reaction was dominated by polyether dipole repolarization kinetics. ${ }^{13}$ That study also, however, revealed an even stronger (proportional) correlation between $k_{\mathrm{EX}}$ and the diffusivity $\left(D_{\mathrm{CION}}\right)$ of the melt counterion. The possibility of a different kind of solvent-based rate control of electron transfer was raised and termed ion atmosphere relaxation. In the present study, we set out to assess the relation of both $k_{\mathrm{EX}}$ and $k_{\mathrm{HET}}$ to both $D_{\mathrm{PHYS}}$ and $D_{\mathrm{CION}}$, in several redox polyether hybrid melts. The observations for both $\mathrm{Co}(\mathrm{III} / \mathrm{II})$ and $\mathrm{Co}(\mathrm{II} / \mathrm{I})$ reactions show that their rates vary in a 1:1 proportionality with $D_{\mathrm{CION}}$, consistent with an ion atmosphere relaxation control.

\section{Experimental Section}

Synthesis of (Na)(MePEG $\left.{ }_{350} \mathbf{S O}_{3}\right)$. This was prepared by a previous $^{14}$ procedure, modified as described in Supporting Information.

Synthesis of $\left[\mathbf{C o}(\text { phen })_{3}\right] \mathbf{C l}_{2} \cdot \mathrm{CoCl}_{2} \cdot 6 \mathrm{H}_{2} \mathrm{O}$ dissolved in ethanol was added dropwise to an excess of sublimed phenanthroline in ethanol while stirring; the phenanthroline solution changed from clear to brown. After the solution was stirred thoroughly, it was concentrated through rotary evaporation, heated, then cooled to $5^{\circ} \mathrm{C}$. Crystals were collected and rinsed with cold ethanol. Purity was checked with UV-vis spectroscopy.

Synthesis of $\left[\mathrm{Co}(\text { phen })_{3}\right]\left(\mathrm{MePEG}_{350} \mathrm{SO}_{3}\right)_{2}$. A published literature procedure was used. ${ }^{3 \mathrm{~b}}$ Anal. Calcd C, 54.3; H, 6.00; N, 5.76; S, 4.40; Co, 4.04; Na, 0; Cl, 0. Found (average of 5 determs.): C, 53.2( \pm 2$)$; H, 6.38( \pm 0.2$)$; N, 5.71( \pm 0.7$)$; S, 4.45( \pm 0.3$)$; Co, 4.22( \pm 0.7$)$; Na, 0.296( \pm 0.6$)$; Cl, 0.293( \pm 0.2$)$.

Synthesis of $\left(\mathbf{N H}_{4}\right)\left(\mathrm{MePEG}_{350} \mathbf{S O}_{3}\right)$. An aqueous solution of $\sim 300 \mathrm{mg}(\mathrm{Na})\left(\mathrm{MePEG}_{350}-\mathrm{SO}_{3}\right)(0.7 \mathrm{mmol})$ was passed through a cation exchange column in the $\mathrm{H}^{+}$form (pretreated with $4 \mathrm{M}$ $\mathrm{HCl})$, the eluent dripping into $17.2 \mathrm{~mL}(0.0687 \mathrm{~mol})$ of ammonium hydroxide chilled in an ice bath. The resulting solution, still in the ice bath, was stirred for $30 \mathrm{~min}$, and then for $30 \mathrm{~min}$ at room temperature. Water and excess ammonia were removed by rotary evaporation and with a vacuum pump on a Schlenk line. The product was dissolved in methylene chloride, filtered through $0.2-\mu \mathrm{m}$ Nalgene PTFE syringe filters, and dried under vacuum.

Plasticization of $\left[\mathrm{Co}(\text { phen })_{3}\right]\left(\mathrm{MePEG}_{350} \mathrm{SO}_{3}\right)_{2}$. Weighed amounts of $\mathrm{MePEG}_{350}$ and $\left(\mathrm{NH}_{4}\right)\left(\mathrm{MePEG} \mathrm{P}_{30} \mathrm{SO}_{3}\right)$ plasticizers were added as described in Supporting Information. The quantities of plasticizer added are stated as moles plasticizer/ moles Co.

Synthesis of $\left[\mathrm{Co}\left(\mathrm{P}_{n} \mathrm{M}\right)_{3}\right]\left(\mathrm{ClO}_{4}\right)_{2}(n=2$ or 3$), \mathbf{I I}_{n}$. The $\mathbf{I I}_{n}$ propylene oxide oligomer-tailed complexes were prepared as previously described. ${ }^{2}$ In the preparation of $\left[\mathrm{Co}\left(\mathrm{P}_{3} \mathrm{M}\right)_{3}\right]\left(\mathrm{ClO}_{4}\right)_{2}$ ( $\left.\mathbf{I I}_{3}\right)$, a stoichiometric excess of the tailed bpy ligand was mixed with a $\mathrm{Co}$ (II) salt. The subsequent cleanup steps were only partly successful in removing the excess ligand, and the several preparations contained varied, residual amounts of tailed ligand (analyzed by nmr), which acts as plasticizer. ${ }^{2}$ In one case (Table 3 ), a larger amount of tailed bpy ligand was deliberately added after cleanup.

Electrochemical Measurements. Potential step chronoamperometry of the $\mathrm{Co}(\mathrm{III} / \mathrm{II})$ and $\mathrm{Co}(\mathrm{II} / \mathrm{I})$ electrochemical

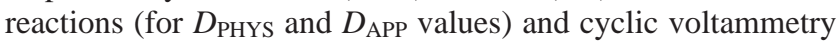
of the $\mathrm{Co}(\mathrm{III} / \mathrm{II})$ reaction (for $k_{\mathrm{HET}}$ ) were conducted on neat films of the redox polyether hybrids resting on microelectrode assemblies, as before. ${ }^{1}$ For measurements of $\left[\mathrm{Co}(\mathrm{phen})_{3}\right]$ $\left(\mathrm{MePEG}_{350} \mathrm{SO}_{3}\right)_{2}(\mathbf{I})$, the melt rested on an epoxy disk with exposed electrode wire tips, Pt (radius $=15 \mu \mathrm{m}$ ) microdisk working electrode, $\mathrm{Pt}$ counter electrode, and $\mathrm{Ag}$ quasireference electrode, as done before. ${ }^{1}$ See Supporting Information for further details. The working electrode in studies of $\left[\mathrm{Co}\left(\mathrm{P}_{n} \mathrm{M}\right)_{3}\right]-$ $\left(\mathrm{ClO}_{4}\right)_{2}\left(\mathbf{I I}_{\boldsymbol{n}}\right)$ melts were either Pt microdisks (radius $=5,13$, 50 , or $95 \mu \mathrm{m}$ ) as above or Pt microbands, ${ }^{2,15}$ fashioned in one case by exposing the edge of a $2.7-\mu \mathrm{m}$ Pt foil (area $3.1 \times 10^{-3}$ 
TABLE 1: Physical Dynamics and Electron-Transfer Results for $\left[\mathrm{Co}(\text { phen })_{3}\right]\left(\mathrm{MePEG}_{350} \mathrm{SO}_{3}\right)_{2}$ with Added MePEG $_{350}$ Plasticizer

\begin{tabular}{|c|c|c|c|c|}
\hline $\begin{array}{l}\text { moles } \mathrm{MePEG}_{350} / \mathrm{Co} \\
\quad \text { complex }\end{array}$ & $0.65: 1$ & $2: 1$ & $3: 1$ & $6: 1^{a}$ \\
\hline concentration $(\mathrm{M})^{b}$ & 0.74 & 0.57 & 0.47 & 0.33 \\
\hline$\delta(\AA)^{c}$ & 13.1 & 14.3 & 15.2 & 17.1 \\
\hline$D_{\text {PHYS }}{ }^{d}\left(25^{\circ} \mathrm{C}\right)\left(\mathrm{cm}^{2} / \mathrm{s}\right)$ & $5.3 \times 10^{-12}$ & $1.3 \times 10^{-10}$ & $4.3 \times 10^{-10}$ & $4.4 \times 10^{-9}$ \\
\hline$D_{\mathrm{CION}^{e}}\left(25^{\circ} \mathrm{C}\right)\left(\mathrm{cm}^{2} / \mathrm{s}\right)$ & $\mathrm{na}^{m}$ & $1.9 \times 10^{-9 n}$ & $3.3 \times 10^{-9}$ & $2.0 \times 10^{-8}$ \\
\hline$D_{\mathrm{APP}}{ }^{f}\left(25^{\circ} \mathrm{C}\right)\left(\mathrm{cm}^{2} / \mathrm{s}\right)$ & na & $3.4 \times 10^{-9}$ & $7.9 \times 10^{-9}$ & $4.5 \times 10^{-8}$ \\
\hline $\begin{array}{l}D_{\mathrm{E}^{g}}^{g}\left(25^{\circ} \mathrm{C}\right) \mathrm{Co}^{\mathrm{II} / \mathrm{I}} \\
\left(\mathrm{cm}^{2} / \mathrm{s}\right)\end{array}$ & na & $3.3 \times 10^{-9}$ & $7.5 \times 10^{-9}$ & $4.1 \times 10^{-8}$ \\
\hline$E_{\mathrm{A}, \mathrm{PHYS}}{ }^{h}(\mathrm{~kJ} / \mathrm{mol})$ & na & 60 & 54 & 43 \\
\hline$E_{\mathrm{A}, \mathrm{ION}}^{i}(\mathrm{~kJ} / \mathrm{mol})$ & na & 46 & 39 & 32 \\
\hline$E_{\mathrm{A}, \mathrm{EX}}{ }^{h}(\mathrm{~kJ} / \mathrm{mol})$ & na & 47 & 41 & 30 \\
\hline$k_{\mathrm{EX}}\left(25^{\circ} \mathrm{C}\right)\left(\mathrm{M}^{-1} \mathrm{~s}^{-1}\right)$ & na & $1.7 \times 10^{6}$ & $4.1 \times 10^{6}$ & $2.5 \times 10^{7}$ \\
\hline$k^{0} \mathrm{EX}^{k}\left(\mathrm{M}^{-1} \mathrm{~s}^{-1}\right)$ & na & $3.4 \times 10^{14}$ & $5.0 \times 10^{13}$ & $4.4 \times 10^{12}$ \\
\hline$k_{\mathrm{HET}}^{l}\left(25^{\circ} \mathrm{C}\right)(\mathrm{cm} / \mathrm{s})$ & $1.0 \times 10^{-7}$ & $1.1 \times 10^{-6}$ & $1.5 \times 10^{-6}$ & na \\
\hline
\end{tabular}

${ }^{a}$ Data presented for $6: 1 \mathrm{~mol} \mathrm{MePEG}_{350}$ is at $30{ }^{\circ} \mathrm{C}$. $D_{\text {PHYs }}$ is calculated from microdisk equation. ${ }^{19}{ }^{b}$ Concentrations are calculated from density measurements: $\rho=1.24 \mathrm{~g} / \mathrm{mL}$ for $0.65: 1 \mathrm{MePEG}_{350} ; 1.23$ $\mathrm{g} / \mathrm{mL}$ for $2: 1 \mathrm{MePEG}_{350} ; 1.18 \mathrm{~g} / \mathrm{mL}$ for $3: 1 \mathrm{MePEG}_{350} ; 1.18 \mathrm{~g} / \mathrm{mL}$ for $6: 1 \mathrm{MePEG}_{350 .}{ }^{c} \delta$ is redox center-center distance calculated from the density assuming cubic packing. ${ }^{d}$ From $\mathrm{Co}(\mathrm{III} / \mathrm{II})$ reaction, Cottrell slope chronoamperometry. ${ }^{18}$ Each value is an average of 2 or 3 trials. ${ }^{e}$ Calculated from eq 2 . Each value is an average of 2 or 3 trials. ${ }^{f}$ From microdisk equation. ${ }^{19}{ }^{g}$ Calculated via eq 1 . Each value is an average of 2 or 3 trials. ${ }^{h}$ From slopes of activation plots in Figure $4 .{ }^{i}$ From slopes of activation plots in Supporting Information. ${ }^{j}$ Calculated via eq $1 .{ }^{k}$ Intercepts of activation plots of $k_{\mathrm{EX}}$ (Figure 4$) .{ }^{l}$ Average values given: 5 trials for $3: 1 \mathrm{~mol}, 10$ trials for $2: 1 \mathrm{~mol}, 1$ trial for $0.65: 1 \mathrm{~mol}$. ${ }^{m}$ Data not available. ${ }^{n}$ Values for 2:1 mol calculated assuming 1:1 ion pairing between cobalt cation and sulfonate anion (ref 21).

$\mathrm{cm}^{2}$ ) and in another being a lithographically defined ${ }^{16}$ microband ("LDM", $10 \mu \mathrm{m}$ wide, $A=2.0 \times 10^{-4} \mathrm{~cm}^{2}$ ). The microband electrodes were flanked on both sides by microband reference electrodes, 2-3 $\mu \mathrm{m}$ away, an arrangement making these electrodes exceptionally robust against uncompensated resistance effects. ${ }^{2}$ Films of the cobalt complex melts (ca. $1 \mathrm{~mm}$ thick) were cast onto the microelectrode platforms and thoroughly dried under vacuum (ca. $1 \times 10^{-3}$ Torr) in a temperaturecontrolled cell enclosure at $70{ }^{\circ} \mathrm{C}$ for at least $12 \mathrm{~h}$. Films of the melts were equilibrated at each temperature for at least $1 \mathrm{~h}$ prior to measurements. The temperature of the cell enclosure was controlled as described in Supporting Information.

Cyclic voltammetry and chronoamperometry were performed using a locally built low-current potentiostat. ${ }^{17}$ Experimental control was exercised with a PC interfaced with a Keithley DASHRES 16-Bit A/D board, using locally written software. Ionic conductivities of the melts were measured using a Solartron Model SI 1260 impedance/gain phase analyzer, SI 1287 electrochemical interface combination. Impedance measurements from $1 \mathrm{MHz}$ to $1 \mathrm{~Hz}$ were performed at $0 \mathrm{~V}$ dc bias and $10-$ $50 \mathrm{mV}$ ac amplitude. Conductivity was calculated as the product of the geometric cell constant $\left(22.5 \mathrm{~cm}^{-1}\right.$ for microdisk measurements of melt $\mathbf{I}$ and $0.0848 \mathrm{~cm}^{-1}$ for LDM measurements of melts $\mathbf{I I}_{n}$ ) with resistance taken from the low-frequency real-axis intercept of the complex impedance semicircle.

\section{Results and Discussion}

Mass Transport and Electron-Transfer Rate Measurements. The effect of adding $\mathrm{MePEG}_{350}$ as plasticizer on the microdisk cyclic voltammetry of melt $\mathbf{I},\left[\mathrm{Co}(\mathrm{phen})_{3}\right]\left(\mathrm{MePEG}_{350^{-}}\right.$ $\left.\mathrm{SO}_{3}\right)_{2}$, at $70{ }^{\circ} \mathrm{C}$ is shown in Figure 2. The added plasticizer causes increases in currents for both $\mathrm{Co}$ (II) oxidation (at positive potentials) and $\mathrm{Co}$ (II) reduction (at negative potentials). The general waveshape reflects a mixed radial-

TABLE 2: Physical Dynamics and Electron-Transfer Results for $\left[\mathrm{Co}(\mathrm{phen})_{3}\right]\left(\mathrm{MePEG}_{350} \mathrm{SO}_{3}\right)_{2}$ with $\mathrm{Added}_{(\mathrm{MePEG}} \mathrm{MrO}_{3} \mathrm{SO}_{3}\left(\mathrm{NH}_{4}\right)$ Plasticizer

\begin{tabular}{llllllll}
\hline moles plasticizer/Co & 0 & $1: 1$ & $1.5: 1$ & $2: 1^{f}$ & $3: 1^{f}$ & $4: 1^{f}$ & $5: 1$ \\
conc, $(\mathrm{M})^{a}$ & 0.74 & 0.68 & 0.59 & 0.58 & 0.50 & 0.42 & na \\
density $(\mathrm{g} / \mathrm{mL})$ & na & 1.30 & 1.26 & na & na & na \\
$\delta(\AA)^{b}$ & na & 13.5 & 14.1 & na & na & na \\
$D_{\text {PHYS }^{c}\left(25^{\circ} \mathrm{C}\right)\left(\mathrm{cm}^{2} / \mathrm{s}\right)}$ & $7.1 \times 10^{-13}$ & $5.5 \times 10^{-12}$ & $7.1 \times 10^{-12}$ & $1.0 \times 10^{-11}$ & $2.3 \times 10^{-11}$ & $4.8 \times 10^{-11}$ & $1.6 \times 10^{-11}$ \\
$k_{\mathrm{HET}^{d}}\left(25^{\circ} \mathrm{C}\right)(\mathrm{cm} / \mathrm{s})$ & $3.6 \times 10^{-9}$ & $1.1 \times 10^{-7}$ & $1.1 \times 10^{-7}$ & $1.7 \times 10^{-7}$ & $3.0 \times 10^{-7}$ & $3.2 \times 10^{-7}$ & $1.3 \times 10^{-7}$
\end{tabular}

${ }^{a}$ Concentrations are calculated from density measurements. Calculated as (moles of melt + moles of plasticizer)/(liters of melt + liters of plasticizer). ${ }^{b} \delta$ is redox center-center distance taken from the molecular volume assuming packed cubes. ${ }^{c}$ From Co(III/II) reaction, Cottrell slope chronoamperometry. ${ }^{18}$ Values are averages from 2-4 trials except for 0 mol that is a single trial value. ${ }^{d}$ From Nicholson-Shain analysis. ${ }^{22}$ Each value is an average from 2 to 4 trials except for the 1.5 and 4 trials which are only one. See Supporting Information for full scan rate dependent data. ${ }^{e}$ Data not available. ${ }^{f}$ Concentrations of 2:1, 3:1, and 4:1 $\left(\mathrm{MePEG}_{350} \mathrm{SO}_{3}\right)\left(\mathrm{NH}_{4}\right)$ were extrapolated from a plot of concentration vs moles $\left(\mathrm{MePEG}_{350} \mathrm{SO}_{3}\right)\left(\mathrm{NH}_{4}\right)$ :Co because insufficient material was available for density measurements of those samples.

TABLE 3: Physical Dynamics and Electron-Transfer Results for $\operatorname{Co}\left(\operatorname{bpy}\left(\mathrm{P}_{n} \mathrm{M}\right)_{2}\right)_{3}\left(\mathrm{ClO}_{4}\right)_{2}$

\begin{tabular}{|c|c|c|c|c|c|c|c|c|c|c|c|c|}
\hline melt & $\begin{array}{l}\text { density } \\
\mathrm{g} / \mathrm{cm}^{3}\end{array}$ & $\begin{array}{c}\text { conc } \\
\mathrm{M}^{a}\end{array}$ & $\begin{array}{l}\delta \\
\AA\end{array}$ & $\begin{array}{l}\text { mol \% } \\
\text { plast. }^{c}\end{array}$ & $\begin{array}{c}\text { trial } \\
\text { no. }\end{array}$ & $\begin{array}{c}D_{\mathrm{PHYS}} 25^{\circ} \mathrm{C} \\
\mathrm{cm}^{2} / \mathrm{s}\end{array}$ & $\begin{array}{c}D_{\mathrm{CION}} 25^{\circ} \mathrm{C} \\
\mathrm{cm}^{2} / \mathrm{s}\end{array}$ & $\begin{array}{c}k_{\mathrm{HET}} 25^{\circ} \mathrm{C} \\
\mathrm{cm} / \mathrm{s}\end{array}$ & $\begin{array}{l}E_{\mathrm{A}, \mathrm{PHYS}} \\
\mathrm{kJ} / \mathrm{mol}\end{array}$ & $\begin{array}{l}E_{\mathrm{A}, \mathrm{CION}} \\
\mathrm{kJ} / \mathrm{mol}\end{array}$ & $\begin{array}{l}E_{\mathrm{A}, \mathrm{HET}} \\
\mathrm{kJ} / \mathrm{mol}\end{array}$ & $\begin{array}{l}k^{0} \mathrm{HET} \\
\mathrm{cm} / \mathrm{s}\end{array}$ \\
\hline \multirow{11}{*}{$\mathrm{Co}\left(\mathrm{P}_{3} \mathrm{M}\right)_{3}$} & 1.21 & 0.57 & 14.3 & $<1$ & 1 & $4.9 \times 10^{-16}$ & $\mathrm{na}^{d}$ & $2.0 \times 10^{-10}$ & na & na & na & na \\
\hline & & & & 5.1 & 1 & $3.2 \times 10^{-15}$ & na & $2.5 \times 10^{-9}$ & na & na & na & na \\
\hline & & & & & 2 & $2.0 \times 10^{-14}$ & na & $3.8 \times 10^{-9}$ & na & na & na & na \\
\hline & & & & & 3 & $6.4 \times 10^{-14}$ & na & $3.1 \times 10^{-9}$ & na & na & na & na \\
\hline & & & & 36 & 1 & $6.1 \times 10^{-12}$ & na & $5.1 \times 10^{-8}$ & na & na & na & na \\
\hline & & & & 5 & 1 & $1.6 \times 10^{-14}$ & $4.3 \times 10^{-12}$ & $2.4 \times 10^{-9}$ & $108( \pm 2)$ & $66( \pm 2)$ & $69( \pm 1)$ & $3.4( \pm 0.1) \times 10^{3}$ \\
\hline & & & & & 2 & $7.1 \times 10^{-15}$ & $4.3 \times 10^{-12}$ & $1.6 \times 10^{-8}$ & $130( \pm 4)$ & & $64( \pm 3)$ & $3.4( \pm 0.1) \times 10^{3}$ \\
\hline & & & & & 3 & $1.5 \times 10^{-14}$ & $4.3 \times 10^{-12}$ & $1.3 \times 10^{-9}$ & $99( \pm 16)$ & & $72( \pm 12)$ & $9.2( \pm 4.3) \times 10^{3}$ \\
\hline & & & & & 4 & na & na & na & $104( \pm 4)$ & & $65( \pm 4)$ & $2.0( \pm 0.4) \times 10^{3}$ \\
\hline & & & & & 5 & $2.3 \times 10^{-15}$ & $4.4 \times 10^{-12}$ & $6.7 \times 10^{-9}$ & $76( \pm 13)$ & & $\mathrm{e}$ & $\mathrm{e}$ \\
\hline & & & & & 6 & $5.9 \times 10^{-15}$ & $4.3 \times 10^{-12}$ & $1.1 \times 10^{-8}$ & $131( \pm 4)$ & & $65( \pm 7)$ & $2.2( \pm 0.7) \times 10^{3}$ \\
\hline \multirow[t]{2}{*}{$\mathrm{Co}\left(\mathrm{P}_{2} \mathrm{M}\right)_{3}$} & 1.26 & 0.71 & 13.3 & 1 & 1 & $2.0 \times 10^{-17}$ & $1.2 \times 10^{-13}$ & $2.7 \times 10^{-11}$ & $135( \pm 7)$ & $133( \pm 2)$ & e & $\mathrm{e}$ \\
\hline & & & & 8 & 1 & $3.2 \times 10^{-15}$ & na & $1.1 \times 10^{-10}$ & $\mathrm{e}$ & na & $66( \pm 9)$ & $4.4( \pm 3.9) \times 10^{1}$ \\
\hline
\end{tabular}

${ }^{a}$ Concentrations are calculated from density measurements. ${ }^{b} \delta$ is redox center-center distance taken from the molecular volume assuming packed cubes, using the given values for density. ${ }^{c}$ The plasticizer used is 2,2'-bipyridyl-4,4'-bis(tripropylene glycol monomethyl ether carboxylate) $\left(\mathrm{P}_{3} \mathrm{M}\right)$ for all $\mathrm{Co}\left(\mathrm{P}_{3} \mathrm{M}\right)_{3}$ samples except for the 5\% sample, which is plasticized with $\mathrm{Co}\left(\mathrm{ClO}_{4}\right)_{2}\left(\mathrm{H}_{2} \mathrm{O}\right)_{6}$. The plasticizer used for the $\mathrm{Co}\left(\mathrm{P}_{2} \mathrm{M}\right)_{3}$ samples is 2,2'-bipyridyl-4,4'-bis(dipropylene glycol monomethyl ether carboxylate) $\left(\mathrm{P}_{2} \mathrm{M}\right) .{ }^{d}$ Data not available. ${ }^{e}$ Outlier results not reported. 


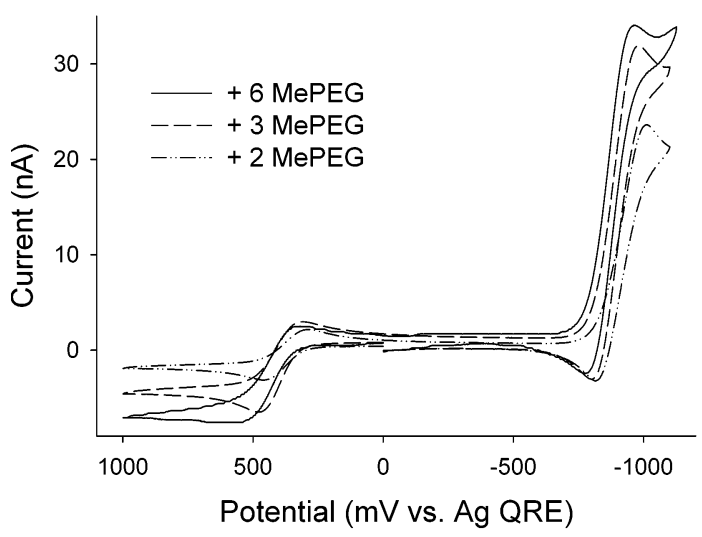

Figure 2. Cyclic voltammetry at $5 \mathrm{mV} / \mathrm{s}$ and $70{ }^{\circ} \mathrm{C}$ of $\left[\mathrm{Co}(\text { phen })_{3}\right]-$ $\left(\mathrm{MePEG}_{350} \mathrm{SO}_{3}\right)_{2}$ melt at a $15-\mu \mathrm{m}$ radius $\mathrm{Pt}$ microdisk electrode with $6: 1,3: 1$, and $2: 1 \mathrm{~mol}$ plasticizer/moles Co complex. $k_{\mathrm{EX}}$ is $2.5 \times 10^{7}$, $4.1 \times 10^{6}$, and $1.7 \times 10^{6} \mathrm{M}^{-1} \mathrm{~s}^{-1}$, and $D_{\text {PHYS }}$ is $4.4 \times 10^{-9}, 4.3 \times$ $10^{-10}$, and $1.3 \times 10^{-10} \mathrm{~cm}^{2} / \mathrm{s}$ respectively for $+6,+3$, and $+2 \mathrm{~mol}$ added plasticizer.

linear diffusion geometry and quasireversibility for the Co(III/ II) reaction. Figure 3 shows further examples of $\mathrm{Co}(\mathrm{III} / \mathrm{II})$ voltammetry, for I plasticized by different amounts of $\left(\mathrm{NH}_{4}\right)\left(\mathrm{MePEG}_{350} \mathrm{SO}_{3}\right)$ (Figure 3A) and for $\mathbf{I I}_{2},\left[\mathrm{Co}\left(\mathrm{P}_{2} \mathrm{M}\right)_{3}\right]-$ $\left(\mathrm{ClO}_{4}\right)_{2}$, at various temperatures (Figure $3 \mathrm{~B}$ ). (The $\mathrm{Co}(\mathrm{II} / \mathrm{I})$ electron-transfer reaction was not part of the experiments on $\mathbf{I I}_{\boldsymbol{n}}$ nor was it studied when I was plasticized with $\left(\mathrm{NH}_{4}\right)$ ( $\mathrm{MePEG}_{350} \mathrm{SO}_{3}$ ), owing to excessive background currents caused by this plasticizer at negative potentials.)

Physical diffusion coefficients ( $D_{\text {PHYS }}$ ) of the Co(II) complexes in the melts were measured with potential step chronoamperometry, stepping from the double layer region in the middle of the Figure 2 voltammogram to the diffusion-controlled

plateau of the $\mathrm{Co}(\mathrm{III} / \mathrm{II})$ wave. Usually, currents could be measured at times sufficiently short to maintain a linear diffusion geometry, and $D_{\text {PHYS }}$ was obtained from the slopes of Cottrell plots (current vs $t^{-1 / 2}$ ). ${ }^{18}$ Results for $D_{\text {PHYS }}$ values at $25^{\circ} \mathrm{C}$ in melt $\mathbf{I}$ are given in Table 1 for $\mathrm{MePEG}_{350}$ plasticizer and in Supporting Information for other temperatures and in Table 2 for melts containing the $\left(\mathrm{NH}_{4}\right)\left(\mathrm{MePEG}{ }_{350} \mathrm{SO}_{3}\right)$ plasticizer. Table

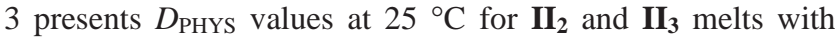
various amounts of plasticizer and in Supporting Information for other temperatures (the sole data point obtained for $\mathbf{I I}_{\mathbf{1}}$ is included in Supporting Information).

Apparent diffusion coefficients $\left(D_{\mathrm{APP}}\right)$ for the reduction of $\mathrm{Co}(\mathrm{II})$ to $\mathrm{Co}(\mathrm{I})$ in $\mathbf{I}$, plasticized with $\mathrm{MePEG}_{350}$, were obtained chronoamperometrically by stepping the electrode potential to the diffusion-controlled plateau of the $\mathrm{Co}(\mathrm{II} / \mathrm{I})$ wave. Charge transport in this case is faster because of $\mathrm{Co}(\mathrm{II} / \mathrm{I})$ electron hopping, and after ca. $10^{3} \mathrm{~s}$, the currents are steady state and controlled by radial diffusion. Diffusion coefficients $\left(D_{\text {APP }}\right)$ obtained from such currents with the microdisk equation ${ }^{19}$ are found in Table 1 . Combining $D_{\text {APP }}$ with $D_{\text {PHYs }}$ (eq 1 ) gives $D_{\mathrm{E}}$ and electron self-exchange rate constant $k_{\mathrm{EX}}$ values, also given in Table 1.

The diffusion coefficients of the $\mathrm{ClO}_{4}{ }^{-}$and $\mathrm{MePEG}_{350} \mathrm{SO}_{3}{ }^{-}$ counterions were evaluated indirectly, based on measured ionic conductivities $\left(\sigma_{\mathrm{ION}}\right)$ and the $\mathrm{D}_{\mathrm{PHYS}}$ of the Co complexes, using the Nernst-Einstein relation ${ }^{20}$

$$
\sigma_{\mathrm{ION}}=F^{2} / R T\left[z_{\mathrm{Co}}^{2} D_{\mathrm{PHYS}} C_{\mathrm{Co}}+z_{\mathrm{CION}}^{2} D_{\mathrm{CION}} C_{\mathrm{CION}}\right]
$$

where $z, D$, and $C$ are charge, diffusion coefficient, and concentration of the indicated species, respectively. Table 1 gives the resulting $D_{\mathrm{CION}}$ values for the $\mathrm{MePEG}_{350} \mathrm{SO}_{3}{ }^{-}$counterion at $25{ }^{\circ} \mathrm{C}$ in the melt $\mathbf{I}$; Table 3 gives $25^{\circ} \mathrm{C} D_{\mathrm{CION}}$ values
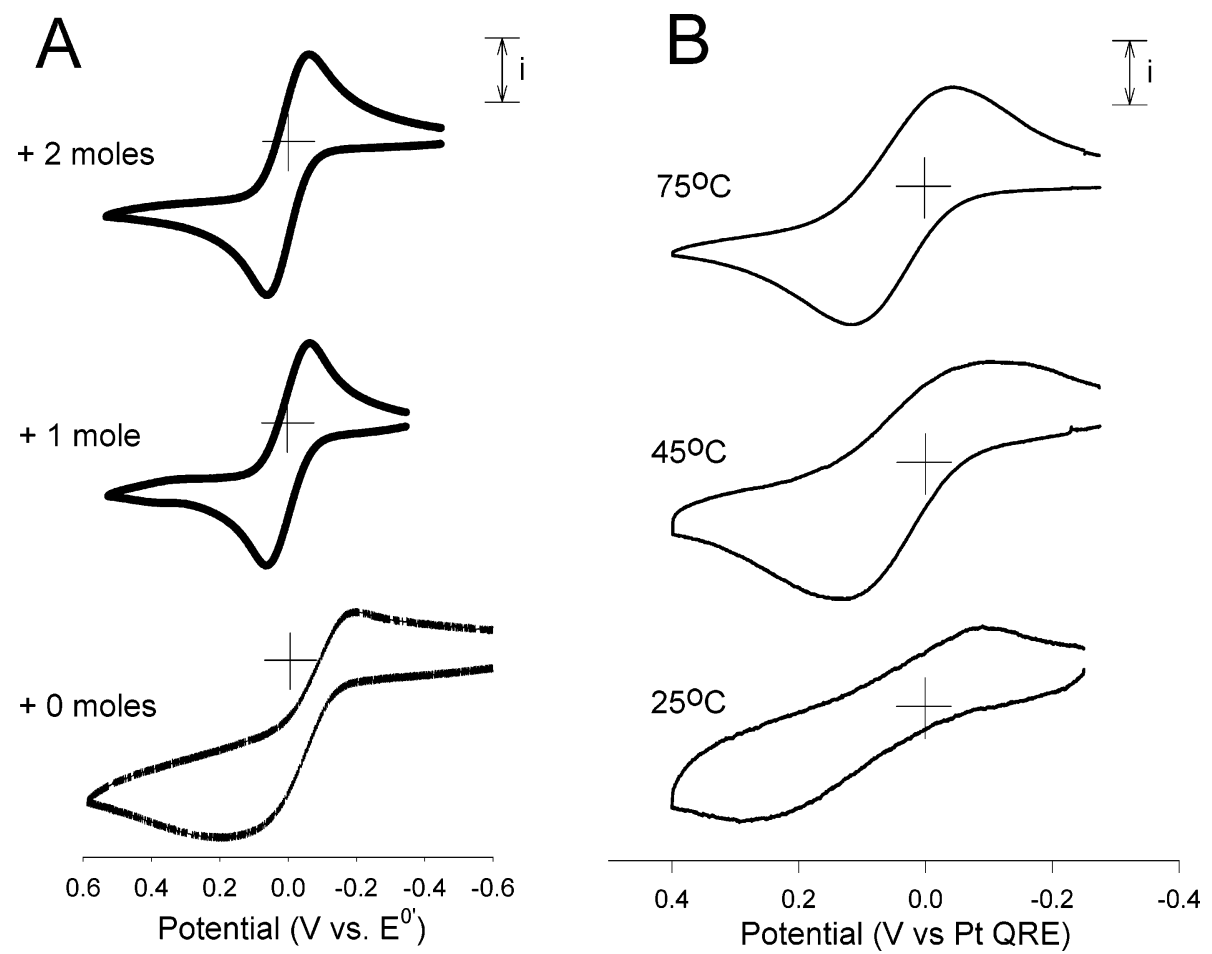

Figure 3. (A) Cyclic voltammetry at $25^{\circ} \mathrm{C}$ and at $0.2 \mathrm{mV} / \mathrm{s}$ of $\left[\mathrm{Co}(\mathrm{phen})_{3}\right]\left(\mathrm{MePEG}_{350} \mathrm{SO}_{3}\right)_{2}$ at a $15-\mu \mathrm{m}$ radius Pt microdisk electrode. Added +2 , +1 , and $0 \mathrm{~mol}$ of $\left(\mathrm{MePEG}_{350} \mathrm{SO}_{3}\right)\left(\mathrm{NH}_{4}\right)$ plasticizer (relative to $\mathrm{Co}$ ) are indicated on plots, for which the current bars are 24,18 , and $3 \mathrm{pA}$, respectively. $k_{\mathrm{HET}}=3.6 \times 10^{-9}, 1.1 \times 10^{-7}$, and $1.7 \times 10^{-7} \mathrm{~cm} / \mathrm{s}$, and $D_{\mathrm{PHYS}}=7.1 \times 10^{-13}, 5.5 \times 10^{-12}$, and $1.0 \times 10^{-11} \mathrm{~cm}^{2} / \mathrm{s}$, respectively. $(\mathrm{B}) \mathrm{Cyclic}$ voltammetry at indicated temperatures of $\left[\mathrm{Co}\left(\mathrm{bpy}\left(\mathrm{P}_{2} \mathrm{M}\right)_{2}\right)_{3}\right]\left(\mathrm{ClO}_{4}\right)_{2}$ at a $2.0 \times 10^{-4} \mathrm{~cm}^{2}$ area microband (LDM). Current bars are 200, 8, and $2 \mathrm{pA}$, potential scan rates are 5,1 , and $0.5 \mathrm{mV} / \mathrm{s}, k_{\mathrm{HET}}=5.3 \times 10^{-8}, 1.6 \times 10^{-9}$, and $2.7 \times 10^{-11} \mathrm{~cm} / \mathrm{s}$, and $D_{\mathrm{PHYS}}=5.8 \times 10^{-14}, 8.2 \times 10^{-16}$, and 2.0 $\times 10^{-17} \mathrm{~cm}^{2} / \mathrm{s}$ for the 75,45 , and $25^{\circ} \mathrm{C}$ trials, respectively. See Supporting Information for scan rate dependent data. 
TABLE 4: Counterion Transport Measured in $\left[\mathrm{Ru}\left(\mathrm{bpy}\left(\mathrm{CO}_{2} \mathrm{MePEG}_{350}\right)_{2}\right)_{3}\right]\left[\mathrm{ClO}_{4}\right]_{2}$ Containing $30 \mathrm{~mol} \%$ of $\left[\mathrm{Ru}\left(\operatorname{bpy}\left(\mathrm{CO}_{2} \mathrm{MePEG}_{350}\right)_{2}\right)_{3}\right][\mathrm{I}]_{2}$ Using Ionic Conductivity and Iodide Oxidation Voltammetry

\begin{tabular}{cccc}
\hline$T^{\circ} \mathrm{C}$ & $\begin{array}{c}D_{\text {IODIDE }} \times 10^{9} \\
\mathrm{~cm}^{2} / \mathrm{s}^{a}\end{array}$ & $\begin{array}{c}\sigma_{\mathrm{ION}} \times 10^{6} \\
\mathrm{mhos}^{-1} \mathrm{~cm}^{-1 b}\end{array}$ & $\begin{array}{c}D_{\mathrm{CION}} \times 10^{9} \\
\mathrm{~cm}^{2} / \mathrm{s}^{c}\end{array}$ \\
\hline 45.0 & 1.3 & 4.7 & 1.5 \\
50.0 & 1.9 & 6.1 & 2.0 \\
55.0 & 2.9 & 7.7 & 2.6 \\
60.0 & 3.9 & 9.7 & 3.3 \\
65.0 & 5.2 & 12 & 4.2
\end{tabular}

${ }^{a}$ Diffusion measurements were based on chronoamperometry. ${ }^{b}$ From AC impedance measurement. ${ }^{c}$ Calculated from eq 2 assuming that $D_{\text {PHYS }}$ of the $\mathrm{Ru}$ complex is negligible.

for the $\mathrm{ClO}_{4}{ }^{-}$counterion in the melt $\mathbf{I I}_{n}$. Supporting Information presents $D_{\text {CION }}$ results at other temperatures. As discussed previously, ${ }^{1 \mathrm{~d}}$ any ion-pairing interactions present would depress the apparent $D_{\mathrm{CION}}$ values, so they represent lower limits. The effect of ion pairing should not be large; assuming complete formation of a 1:1 ion pair for example increases the calculated $D_{\text {CION }}$ by only a factor of $\sim 3$-fold. ${ }^{21}$ Migration effects were also minor. ${ }^{21}$

To verify the indirect $D_{\text {CION }}$ measurements, we conducted a set of direct voltammetric determinations of the diffusion coefficient of another small counterion, iodide, in a closely related $\mathrm{Ru}$ complex melt, $\left.\left[\mathrm{Ru}\left(\mathrm{bpy}\left(\mathrm{MePEG}_{350}\right)_{2}\right)_{3}\right](\mathrm{X})_{2}\right)$ where the $\mathrm{MePEG}_{350}$ oligomer tail was attached to bipyridine ligands and $\mathrm{X}^{-}$is a mixture of $\mathrm{ClO}_{4}{ }^{-}$and $\left(30 \%\right.$ mol percent) $\mathrm{I}^{-}$. Iodide is oxidized to tri-iodide in the voltammetry. The average $D_{\mathrm{CION}}$ was also determined from ionic conductivity of the melts, using eq 2 . Table 4 shows that the directly measured $D_{\text {IODIDE }}$ and the indirectly measured $D_{\mathrm{CION}}$ agree very well. The experiments leading to Table 4 and analogous measurements will be described more fully in another publication. ${ }^{22}$

The Co(III/II) heterogeneous electron-transfer rate constant $\left(k_{\mathrm{HET}}\right)$ was measured from reduction-oxidation separations $\left(\Delta E_{\mathrm{PEAK}}\right)$ between peak currents in cyclic voltammograms as in Figures 2 and 3, using the classical Nicholson approach. ${ }^{23}$ $\Delta E_{\mathrm{PEAK}}$ decreases with increased amounts of plasticizer, reflecting an increase in the reaction rate. The measured $k_{\text {HET }}$ values are generally independent of the potential sweep rate used to obtain the voltammogram (see illustrative data in Supporting Information). The validity of $k_{\mathrm{HET}}$ measurements and the avoidance of $\mathrm{IR}_{\mathrm{UNC}}$ effects in the Co complex melts was thoroughly examined in a recent study. ${ }^{2 \mathrm{~b}} k_{\mathrm{HET}}$ results for the $\mathrm{Co}(\mathrm{III} / \mathrm{II})$ reaction in melt $\mathbf{I}$ with $\mathrm{MePEG}_{350}$ and $\left(\mathrm{NH}_{4}\right)\left(\mathrm{MePEG}_{350^{-}}\right.$ $\mathrm{SO}_{3}$ ) plasticizers are given in Tables 1 and 2, respectively, and in Table 3 and Supporting Information for melt $\mathbf{I I}_{\boldsymbol{n}}$ with various amounts of plasticizer and at other temperatures, respectively.

The temperature dependencies of $k_{\mathrm{EX}}, k_{\mathrm{HET}}, D_{\mathrm{PHYS}}$, and $D_{\mathrm{CION}}$ in melts $\mathbf{I}$ and $\mathbf{I I}_{\boldsymbol{n}}$ are shown in Figure 4 as activation plots; the activation barrier energies are found in Tables $1-3$. Thermal activation prefactors $\left(k_{\mathrm{EX}}{ }^{0}\right.$ and $\left.k_{\mathrm{HET}}{ }^{0}\right)$ derived from the Arrhenius plot intercepts are given in Tables 1 and 3. Complete tables of the temperature-dependent data are found in Supporting Information.

While the activation barrier energies $\left(E_{\mathrm{A}, \mathrm{EX}}\right)$ for the $\mathrm{Co}(\mathrm{II} / \mathrm{I})$ reaction in Table 1 are enthalpies of activation, the reaction entropies and entropies of activation are zero since the reactions are symmetrical (isotopic) self-exchanges. ${ }^{8}, 9 \mathrm{~b}$ The $E_{\mathrm{A}, \mathrm{EX}}$ barriers are thus equated with activation free energies $\left(\Delta G^{*}\right)$, and the $\mathrm{Co}(\mathrm{II} / \mathrm{I})$ reaction rate temperature dependence is expressed by ${ }^{9}$

$$
k_{\mathrm{EX}}=K_{\mathrm{P}} \kappa v_{n} \exp \left[-\Delta G^{*} / R T\right]
$$

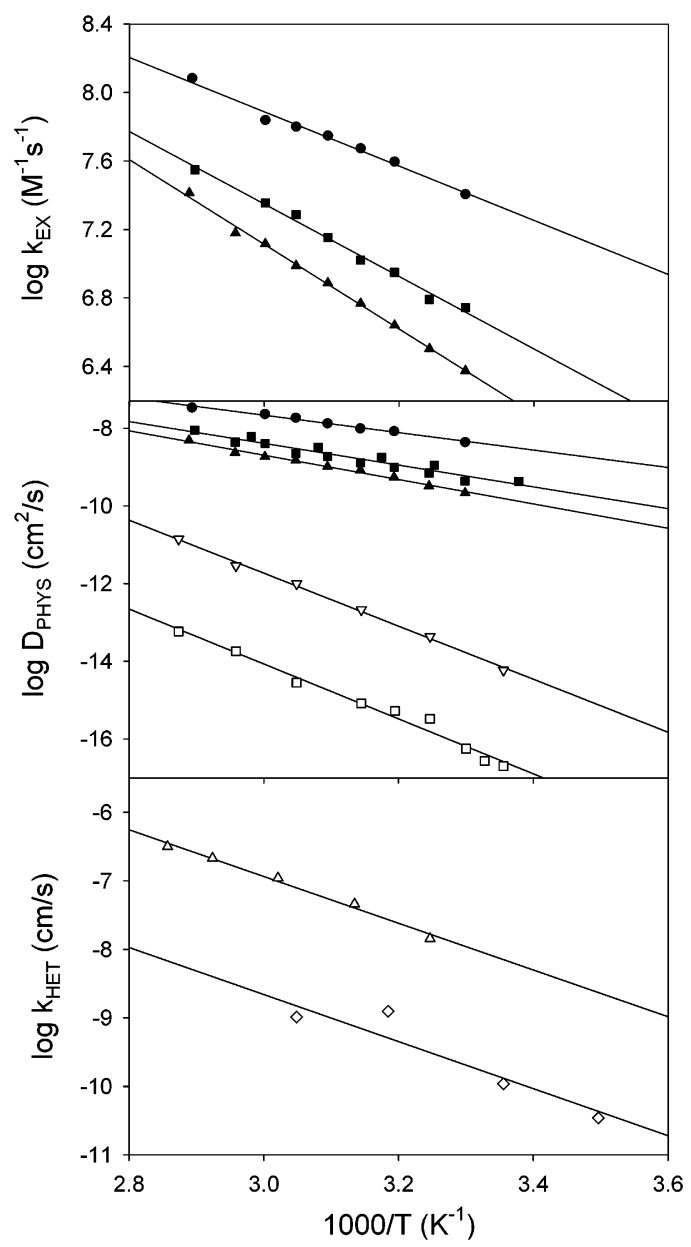

Figure 4. Activation plots of $k_{\mathrm{EX}}\left(\mathrm{M}^{-1} \mathrm{~s}^{-1}\right.$, upper), $D_{\mathrm{PHYs}}\left(\mathrm{cm}^{2} \mathrm{~s}^{-1}\right.$, middle), and $k_{\mathrm{HET}}(\mathrm{cm} / \mathrm{s}$, lower) with different amounts of plasticizer added: 6:1 mol MePEG 350 (৩), 3:1 mol $\operatorname{MePEG}_{350}$ (回), 2:1 mol $\mathrm{MePEG}_{350}(\mathbf{\Lambda})$, relative to moles Co complex, $5 \% \mathrm{Co}\left(\mathrm{ClO}_{4}\right)_{2}\left(\mathrm{H}_{2} \mathrm{O}\right)_{6}$ representative trials $(\triangle, \nabla), 1 \% \mathrm{P}_{2} \mathrm{M}(\square), 8 \% \mathrm{P}_{2} \mathrm{M}(\diamond)$. Filled symbols represent $\left[\mathrm{Co}(\text { phen })_{3}\right]\left(\mathrm{MePEG}_{350} \mathrm{SO}_{3}\right)_{2}$. Open triangles represent $[\mathrm{Co}-$ (bpy $\left.\left.\left(\mathrm{P}_{3} \mathrm{M}\right)_{2}\right)_{3}\right]\left(\mathrm{ClO}_{4}\right)_{2}$. Open squares and diamonds represent [Co(bpy$\left.\left.\left(\mathrm{P}_{2} \mathrm{M}\right)_{2}\right)_{3}\right]\left(\mathrm{ClO}_{4}\right)_{2}$. See Tables 1 and 3 for activation energy barrier and intercept data and Supporting Information for complete tables of temperature-dependent data.

where the activation enthalpy $E_{\mathrm{A}, \mathrm{EX}} \approx \Delta G^{*}(=\lambda / 4$ where $\lambda$ is reorganization barrier energy), $K_{\mathrm{P}}$ is the donor-acceptor precursor complex formation constant, $\kappa$ the electronic transmission coefficient, $v_{n}$ the nuclear frequency factor, $k_{\mathrm{B}}$ is the Boltzman constant, and $k_{\mathrm{EX}}{ }^{0}=K_{\mathrm{P}} \kappa v_{n}$.

The changes in the rate constants with additional $\mathrm{MePEG}_{350}$ can arise from either changes in the activation barrier energies or in the pre-exponential term, according to eq 3. Comparing the results in Table 1 for 3 and 6 mol of added MePEG 350 plasticizer (relative to moles Co complex), the activation barrier decreases for the latter, with a contravening decrease in the preexponential term $\left(k_{\mathrm{EX}}{ }^{0}=K_{\mathrm{P}} \kappa v_{n}\right)$, leaving the $\mathrm{Co}(\mathrm{II} / \mathrm{I}) k_{\mathrm{EX}}$ a net 6 -fold change. The reaction seems to become less adiabatic as plasticizer is added, but since adiabatic electron-transfer reactions (highly coupled reactant/product potential energy surfaces) have $^{9} \kappa \nu \approx 10^{12}-10^{13} \mathrm{~s}^{-1}$, most of the experiments in Table 1 would appear to fall into the adiabatic category.

Correlations between Electron Transfer and Diffusion Rates. Examination of the results in Tables $1-3$ shows that both $\mathrm{Co}(\mathrm{II} / \mathrm{I})$ and $\mathrm{Co}(\mathrm{III} / \mathrm{II})$ electron-transfer rate constants, $k_{\mathrm{EX}}$ and $k_{\mathrm{HET}}$, increase systematically as the mass transport dynamics 

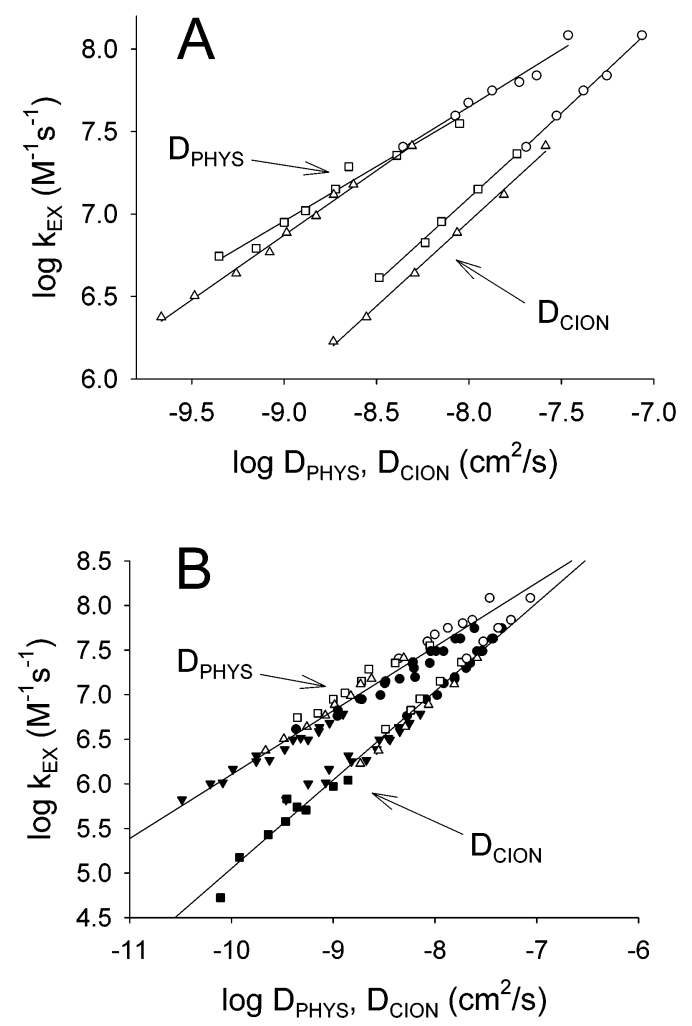

Figure 5. (A) Linear $\log -\log$ relationship between $k_{\mathrm{EX}}\left(\mathrm{M}^{-1} \mathrm{~s}^{-1}\right)$ for the Co(II/I) electron-transfer reaction vs. $D_{\mathrm{PHYS}}\left(\mathrm{cm}^{2} / \mathrm{s}\right)$ and $D_{\mathrm{CION}}\left(\mathrm{cm}^{2} /\right.$ s) in $\left[\mathrm{Co}(\text { phen })_{3}\right]\left(\mathrm{MePEG}_{350} \mathrm{SO}_{3}\right)_{2}$ plasticized with $\mathrm{MePEG}_{350}(6: 1 \mathrm{~mol}$ (O), $3: 1 \mathrm{~mol}(\square), 2: 1 \mathrm{~mol}(\triangle)$, relative to moles Co complex) at a range of temperatures $\left(25-70{ }^{\circ} \mathrm{C}\right)$. Slopes for the $D_{\mathrm{PHYS}}$ and $D_{\mathrm{CION}}$ correlations are $0.7,0.7$, and 0.8 and $1.1,1.0$, and 1.0 , for $6: 1,3: 1$, and 2:1 mol plasticizer relative to Co, respectively. (B) Panel A data (same symbol set) combined with previously published data for [Co(phen $\left.)_{3}\right]-$ $\left(\mathrm{MePEG}_{350} \mathrm{SO}_{3}\right)_{2}{ }^{3 \mathrm{~b}}(\bullet)$ and $\left[\mathrm{Co}\left(\mathrm{bpy}\left(\mathrm{CO}_{2} \mathrm{MePEG}_{350}\right)_{2}\right)_{3}\right]\left(\mathrm{ClO}_{4}\right)_{2}{ }^{3 \mathrm{a}}(\boldsymbol{\nabla})$, both plasticized with liquid $\mathrm{CO}_{2}$ (over a range of temperatures) and $\left[\mathrm{Co}\left(\operatorname{bpy}\left(\mathrm{CO}_{2} \mathrm{MePEG}-350\right)_{2}\right)_{3}\right]\left(\mathrm{ClO}_{4}\right)_{2}+x \mathrm{LiClO}_{4}{ }^{1 \mathrm{~d}}(\mathbf{\square})(x=0-1.31)$. The open panel B data symbols are the same as for panel A. Slope for the $D_{\mathrm{PHYS}}$ correlation is 0.7 , and slope for the $D_{\mathrm{CION}}$ correlation is 1.0. See Figure S2 in Supporting Information for a colored version of this figure.

parameters increase. These correlations are shown in Figures 5 and 6 , respectively.

Figure 5A displays the new results of this study for melt $\mathbf{I}$ as $\log -\log$ plots of the homogeneous $\mathrm{Co}(\mathrm{II} / \mathrm{I})$ constant $k_{\mathrm{EX}}\left(\mathrm{M}^{-1}\right.$ $\left.\mathrm{s}^{-1}\right)$ vs. the Co complex self-diffusion constant $D_{\mathrm{PHYS}}\left(\mathrm{cm}^{2} / \mathrm{s}\right)$ and the $\mathrm{MePEG}_{350} \mathrm{SO}_{3}{ }^{-}$counterion diffusion constant $D_{\mathrm{CION}}$ $\left(\mathrm{cm}^{2} / \mathrm{s}\right)$, both over a series of temperatures $\left(25-70{ }^{\circ} \mathrm{C}\right)$. The data sets for different levels of plasticization of $\mathbf{I}$ with $\mathrm{MePEG}_{350}$ (6:1 (O), 3:1 ( $\square)$, and 2:1 $(\triangle)$ mol plasticizer/Co) are substantially consistent with one another and give slopes for the $D_{\mathrm{PHYS}}$ correlations of $0.7,0.7$, and 0.8 and, for the $D_{\text {CION }}$ correlation, slopes of 1.1, 1.0, and 1.0, respectively. These new results are consistent with and extend earlier data on the $\mathrm{Co}$ (II/I) electrontransfer reaction rate in melt $\mathbf{I}$ and in another Co complex melt where the plasticization was accomplished in different ways. Figure 5B presents the new (open symbols) and previous data together, again taken over a series of temperatures, where melt $\mathbf{I}^{\mathrm{bb}}(\mathbf{O})$ and the melt $\left[\mathrm{Co}\left(\mathrm{bpy}\left(\mathrm{CO}_{2} \mathrm{MePEG}_{350}\right)_{2}\right)_{3}\right]\left(\mathrm{ClO}_{4}\right)_{2}{ }^{3 \mathrm{a}}(\boldsymbol{\nabla})$ had been plasticized by contact of the melt film by liquid $\mathrm{CO}_{2}$, and the melt $\left[\mathrm{Co}\left(\mathrm{bpy}\left(\mathrm{CO}_{2} \mathrm{MePEG}-350\right)_{2}\right)_{3}\right]\left(\mathrm{ClO}_{4}\right)_{2}$ contained dissolved $\mathrm{LiClO}_{4}{ }^{1 \mathrm{~d}}(\mathbf{\square})$ (mole ratio $=\sim 0-1.31$ ). In the latter case, added $\mathrm{LiClO}_{4}$ "deplasticizes" the melt through polyether chain cross linking by $\mathrm{Li}^{+}$cation/polyether coordination, resulting in depressed transport and electron-transfer rates. The
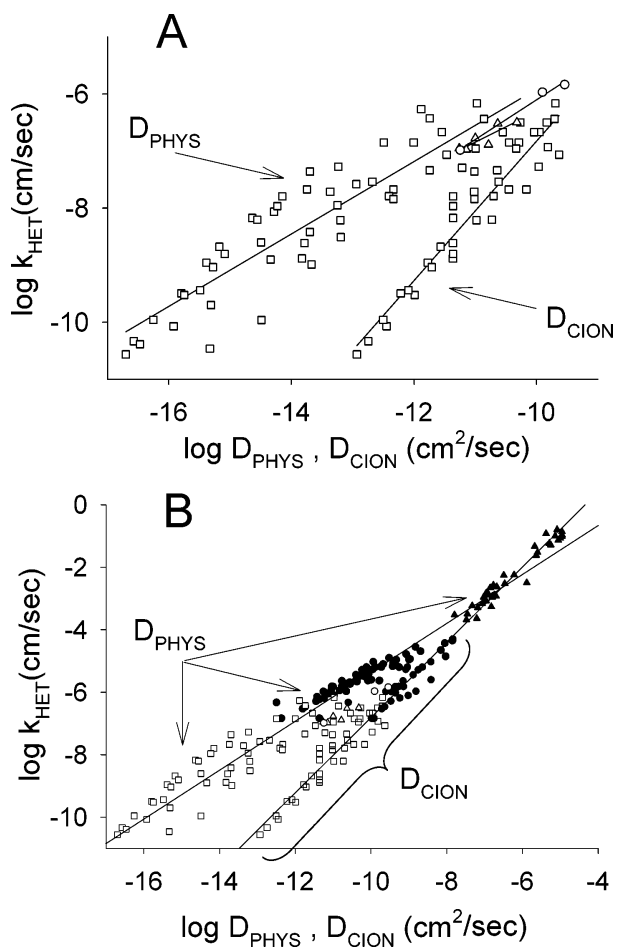

Figure 6. (A) Linear relationship between $k_{\mathrm{HET}}(\mathrm{cm} / \mathrm{s})$ for the $\mathrm{Co}(\mathrm{III} /$ II) electron-transfer reaction and $D_{\mathrm{PHYS}}\left(\mathrm{cm}^{2} / \mathrm{s}\right)$ and $D_{\mathrm{CION}}\left(\mathrm{cm}^{2} / \mathrm{s}\right)$ in $\left[\mathrm{Co}(\text { phen })_{3}\right]\left(\mathrm{MePEG}_{350} \mathrm{SO}_{3}\right)_{2}$ plasticized with $\left(\mathrm{MePEG}_{350} \mathrm{SO}_{3}\right)\left(\mathrm{NH}_{4}\right)(\triangle)$ and $\mathrm{MePEG}_{350}(\mathrm{O})$ and $\left[\mathrm{Co}\left(\mathrm{bpy}\left(\mathrm{P}_{n} \mathrm{M}\right)_{2}\right)_{3}\right]\left(\mathrm{ClO}_{4}\right)_{2}(n=2,3)$ plasticized with $\mathrm{P}_{n} \mathrm{M}(n=2$ and 3$)$ or $\mathrm{Co}\left(\mathrm{ClO}_{4}\right)_{2}\left(\mathrm{H}_{2} \mathrm{O}\right)_{6}(\square)$ over a range of temperatures. Slopes are 0.6 and 1.2 for the $\left[\mathrm{Co}\left(\mathrm{bpy}\left(\mathrm{P}_{n} \mathrm{M}\right)_{2}\right)_{3}\right]\left(\mathrm{ClO}_{4}\right)_{2}$ $D_{\text {PHYS }}$ and $D_{\text {CION }}$ correlations, respectively. Slopes for the $D_{\text {PHYS }}$ correlation of $\left[\mathrm{Co}(\text { phen })_{3}\right]\left(\mathrm{MePEG}_{350} \mathrm{SO}_{3}\right)_{2}$ plasticized with $\mathrm{MePEG}_{350}$ and $\left(\mathrm{MePEG}_{350} \mathrm{SO}_{3}\right)\left(\mathrm{NH}_{4}\right)$ are 0.7 and 0.5 , respectively. (B) Panel A data combined with previously studied $\mathrm{Co}(\text { bpy })_{3}$ melts $^{1 \mathrm{le}}(\bullet)$ and previously studied solutions of $\mathrm{Co}(\mathrm{bpy})_{3}{ }^{10}(\mathbf{\Lambda})$. Panel B open data symbols are the same as for panel A. Slopes are 0.8 and 1.2 for the combined $D_{\mathrm{PHYS}}$ and combined $D_{\mathrm{CION}}$ correlations, respectively. See Figure S3 in Supporting Information for a colored version of this figure.

average slope of the $D_{\text {PHYS }}$ correlation in Figure $5 \mathrm{~B}$ is 0.7 , that for the $D_{\mathrm{CION}}$ correlation is 1.0. See Figure S2 in Supporting Information for a colored version of this figure.

Figure 6 shows an analogous comparison for the heterogeneous $\mathrm{Co}(\mathrm{III} / \mathrm{II})$ electron-transfer rate constants. Figure $6 \mathrm{~A}$ plots the new results in this report (over a series of temperatures) for $\log k_{\mathrm{HET}}(\mathrm{cm} / \mathrm{s})$ vs $\log D_{\mathrm{PHYS}}\left(\mathrm{cm}^{2} / \mathrm{s}\right)$ and vs $D_{\mathrm{CION}}\left(\mathrm{cm}^{2} / \mathrm{s}\right)$ in melt I plasticized with $\left(\mathrm{NH}_{4}\right)\left(\mathrm{MePEG}_{350} \mathrm{SO}_{3}\right)(\triangle)$ and with $\mathrm{MePEG}_{350}(\mathrm{O})$ and in melts $\mathbf{I I}_{\mathbf{2}}$ and $\mathbf{I I}_{\mathbf{3}}$ plasticized as described in the Experimental Section ( $\square$ ). There is substantial scatter but also clear systematic trends in the data for melts $\mathbf{I I}_{\mathbf{2}}$ and $\mathbf{I I}_{\mathbf{3}}$, which extend over a large range of values. The slopes of the correlation plots for $\mathbf{I I}_{\mathbf{2}}$ and $\mathbf{I I}_{\mathbf{3}}$ are 0.6 and 1.2 for $D_{\mathrm{PHYS}}$ and $D_{\text {CION }}$, respectively. Figure $6 \mathrm{~B}$ combines these new results (open symbols) with previous data on the $\mathrm{Co}(\mathrm{III} / \mathrm{II})$ reaction, studied in melts of PEG-tailed $\left[\mathrm{Co}(\text { bpy })_{3}\right]\left(\mathrm{ClO}_{4}\right)_{2}$ complexes $^{1 \mathrm{e}}(\mathbf{O})$ and solutions of $\left[\mathrm{Co}(\mathrm{bpy})_{3}\right]\left(\mathrm{ClO}_{4}\right)_{2}{ }^{10}(\mathbf{\Delta})$ in various solvents including Debye solvents. As in Figure 5B, there is a great consistency of the combined data, for which the $\log -\log$ slopes are 0.8 and 1.2 for $D_{\mathrm{PHYS}}$ and $D_{\mathrm{CION}}$, respectively. The $D_{\mathrm{CION}}$ data are more consistent with $D_{\text {PHYs }}$ results in Debye solvents ${ }^{10}$ (upper right data in Figure $6 \mathrm{~B}$, where $k_{\mathrm{HET}}$ was also directly correlated with known $\tau_{\mathrm{L}}$ values). See Figure S3 in Supporting Information for a colored version of this figure.

Models for Correlations between Electron-Transfer and Mass-Transport Rates. We have recently discussed and compared $^{3}$ two models that rationalize correlations between 
electron-transfer rate constants and physical transport rates such as those in Figures 5 and 6. These are (a) solvent dynamics in the context of the rate of solvent dipole reorganization ${ }^{10,11,12,24,25}$ and (b) a newer model that is a different version of solvent dynamics, termed ion atmosphere relaxation. ${ }^{3}$ These models will be briefly outlined next.

Solvent dynamics electron-transfer rate control in the context of dipolar reorganization time constants refers to adiabatic reactions where the barrier crossing frequency $v_{n}$ is influenced by coupling between the solvent and transition-state motions ${ }^{24}$

$$
v_{n}=\tau_{\mathrm{L}}{ }^{-1}\left[\frac{\Delta G_{\mathrm{OS}}^{*}}{4 \pi R T}\right]^{1 / 2}
$$

where $\Delta G_{\mathrm{OS}}^{*}$ is the outer-sphere reorganizational barrier energy and $\tau_{\mathrm{L}}$ is the longitudinal solvent relaxation time or time constant for solvent dipolar reorganization. The value of $\tau_{\mathrm{L}}$ can be connected to diffusion constants by ${ }^{12,24}$

$$
\tau_{\mathrm{L}}^{-1}=\left(\frac{\epsilon_{\mathrm{S}}}{\epsilon_{\mathrm{OP}}}\right) \frac{3 r_{\mathrm{H}} D}{2 \alpha^{3}}
$$

where $\epsilon_{\mathrm{op}}$ and $\epsilon_{\mathrm{s}}$ are the optical and static dielectric constants, respectively, and $\alpha$ and $r_{\mathrm{H}}$ are molecular and hydrodynamic radii, respectively. Equation 5 provides a relation between $\tau_{\mathrm{L}}$ of a solvent (and thus electron-transfer rate) and the physical diffusivity of a solute diffusing in it. A number of reports have described correlations between heterogeneous ${ }^{1 e, 10,11,12,24,25}$ and homogeneous ${ }^{3}$ electron-transfer rate constants and $\tau_{\mathrm{L}}$ and/or the diffusion coefficient of the reactant (i.e., $D_{\text {PHYS }}$ ), as predicted by eqs 4 and 5 .

The $D_{\text {PHYS }}$ and $D_{\text {CION }}$ plots in Figures 5 and 6 are consistent with eq 5 . The picture drawn is that, in the metal complex melts, the solvent dipoles are considered to be those of the polyether chains, and the repolarization dynamics are associated with the chain segmental motions, as are the rates of physical diffusion of both the metal complexes and their counterions. The slopes of the former, $\log -\log$ correlation between $D_{\text {PHYS }}$ and $k_{\mathrm{EX}}$ and $k_{\mathrm{HET}}$, are less than unity, but it has been seen before, ${ }^{24 \mathrm{~b}, 25}$ and rationalized, ${ }^{26}$ that electron-transfer kinetics can vary with $\tau_{\mathrm{L}}{ }^{-\theta}$, where $\theta$ is between 0 and 1 . Thus, one could interpret the results of Figures 4 and 5 as reflecting some kind of solvent dynamics control in which the dipolar reorganizational frequency and segmental motions of the polyether chains concurrently influence the electron-transfer and mass-transport rates.

The ion atmosphere relaxation model is a newer ${ }^{3}$ picture of how mass transport and electron-transfer rates could vary in parallel manners. In the metal complex melts, when an electron transfer occurs, the associated relocation of the cationic charge must be accompanied by a redistribution of its chargecompensating counterions. On the basis of the "electron-transferfirst" case discussed ${ }^{27}$ in the context of ion pairing effects on electron transfers, one can write for the $\mathrm{Co}(\mathrm{II} / \mathrm{I})$ reaction

$$
\mathrm{X}^{-} \mathrm{Co}^{\mathrm{II}} \mathrm{Co}_{k_{-1}}^{\stackrel{\mathrm{I}_{1}}{\longrightarrow}} \mathrm{X}^{-} \mathrm{Co}^{\mathrm{I}} \mathrm{Co}^{\mathrm{II}} \stackrel{k_{2}}{\longrightarrow} \mathrm{Co}^{\mathrm{I}} \mathrm{Co}^{\mathrm{II}} \mathrm{X}^{-}
$$

where following electron transfer at rate constant $k_{1}$, the counterion redistribution occurs at rate constant $k_{2}$. The counterion mass transport step is in competition with the back electron transfer (rate constant $k_{-1}$ ). The net electron-transfer rate constant is given by

$$
\frac{1}{k_{\mathrm{EX}}}=\frac{1}{k_{1}}+\frac{k_{-1}}{k_{2} k_{1}}
$$

The counterion redistribution can be modeled $^{27}$ as a diffusion process in which an ion diffuses $(D)$ over a distance "a" to relieve the Coulombic imbalance created by the electron transfer

$$
k_{2}=D\left(\frac{\pi}{2 a}\right)^{2}
$$

Thus, if the right-hand term in eq 7 is dominant, the experimental electron-transfer rate constant $k_{\mathrm{EX}}$ becomes proportional to the diffusivity $D$ of the ion atmosphere. In principle, $k_{2}$ refers to the rate of all ionic motions, including those of any added indifferent electrolyte and of the metal complex cation itself. In Tables 1 and 3 , no electrolyte is added and $D_{\mathrm{CION}}>D_{\mathrm{PHYS}}$. Thus, the dominant ion atmosphere transport in the Co complex melts is expected to be of the $\mathrm{ClO}_{4}{ }^{-}$and $\mathrm{MePEG}_{350} \mathrm{SO}_{3}{ }^{-}$ counterions, which are measured by $D_{\mathrm{CION}}$. The ion atmosphere relaxation model, when the right-hand term of eq 7 is dominant, predicts that the net rate of electron transfers, whether the electron transfers are heterogeneous $\left(k_{\mathrm{HET}}\right.$ for $\left.\mathrm{Co}(\mathrm{III} / \mathrm{II})\right)$ or homogeneous ( $k_{\mathrm{EX}}$ for $\left.\mathrm{Co}(\mathrm{II} / \mathrm{I})\right)$, should be directly proportional to the counterion diffusivity $D_{\mathrm{CION}}$. This is indeed what is found in Figures 5 and 6, making the ion atmosphere model a plausible alternative to the solvent dipolar reorganization dynamics model discussed above.

On what basis can one gauge which model is the more appropriate explanation? The following points are relevant: (a) The correlation of $k_{\mathrm{EX}}$ and $k_{\mathrm{HET}}$ with $D_{\mathrm{CION}}$ is more closely $1: 1$ than with $D_{\text {PHYs. }}$ (b) In the ion atmosphere relaxation model, the net electron transfer rate is not actually governed by the electron-transfer step. Therefore the electron diffusion coefficient by which $k_{\mathrm{EX}}$ is measured for the $\mathrm{Co}(\mathrm{II} / \mathrm{I})$ reaction should equal that of the counterion, and the activation barrier energy for the electron transfer should be that of ionic conductivity (from which $D_{\text {CION }}$ is obtained). The data in Table 1 and in a previous study using $\mathrm{CO}_{2}$ plasticization ${ }^{3}$ show that these parameters are indeed quite close to one another. (c) Finally, the time scales for the $\mathrm{Co}(\mathrm{III} / \mathrm{II})$ and $\mathrm{Co}(\mathrm{II} / \mathrm{I})$ electron transfers are rather different. In the context of the solvent dipole reorganization model, this is in conflict with the supposition that the solvent reorganizational time constants are of the same magnitude as the barrier-crossing frequency. The polyether melt would have to exhibit a very wide dispersion of repolarization time constants to simultaneously accommodate the results in Figures 5 and 6, which span many orders of magnitude of time scale. There is no conflict with the ion atmosphere model, on the other hand, since the experimental electron transfer rate is actually of the counterion. (d) Finally, in regard to the behavior of the heterogeneous rate constant $k_{\mathrm{HET}}$, a classical Frumkin effect is an unlikely explanation since the cobalt melt is a concentrated material and overall concentration gradients of the metal complex are difficult to imagine. Likewise, while the interfacial potential gradient could be distorted by the size difference between the cobalt complex and its counterion, it is difficult to conceive how this could systematically change with melt fluidity.

Our overall conclusion is that the ion atmosphere relaxation model is a better representation of the electron-transfer dynamics in the Co complex melt.

Acknowledgment. This research is supported in part by the Department of Energy, Division of Basic Sciences.

Supporting Information Available: Supplementary information on synthesis, electrodes, temperature-controlled cell, temperature dependence of $D_{\mathrm{PHYS}}, D_{\mathrm{CION}}, \sigma, k_{\mathrm{EX}}$, and $k_{\mathrm{HET}}$, and 
scan-rate dependence of $k_{\mathrm{HET}}$ is available free of charge via the Internet at http://pubs.acs.org.

\section{References and Notes}

(1) (a) Dickinson V, E.; Masui, H.; Williams, M. E.; Murray, R. W. J. Phys. Chem. B 1999, 103, 11028. (b) Dickinson V, E.; Williams, M. E.; Hendrickson, S. M.; Masui, H.; Murray, R. W. J. Am. Chem. Soc. 1999, 121, 613. (c) Williams, M. E.; Masui, H.; Long, J. W.; Malik, J.; Murray, R. W. J. Am. Chem. Soc. 1997, 199, 11997. (d) Williams, M. E.; Lyons, L. J.; Long, J. W.; Murray, R. M. J. Phys. Chem. 1997, 101, 7584. (e) Williams, M. E.; Crooker, J. C.; Pyati, R.; Lyons, L. J.; Murray, R. W. J. Am. Chem. Soc. 1997, 119, 10249. (f) Velazquez, C. S.; Hutchison, J. E.; Murray, R. W. J. Am. Chem. Soc. 1993, 115, 7896. (g) Poupart, M. W.; Velazquez, C. S.; Hassett, K.; Porat, Z.; Haas, O.; Terrill, R. H.; Murray, R. W. J. Am. Chem. Soc. 1994, 116, 1165. (h) Kulesza, P. J.; Dickinson V, E.; Williams, M. E.; Hendrickson, S. M.; Malik, M. A.; Miecznikowski, K.; Murray, R. W. J. Phys. Chem. B 2001, 105, 5833.

(2) (a) Crooker, J. C.; Murray, R. W. J. Phys. Chem. B. 2001, 105, 8704. (b) Crooker, J. C.; Murray, R. W. Anal. Chem. 2000, 72, 32453252 .

(3) (a) Lee, D.; Hutchison, J. C.; Leone, A. M.; DeSimone, J. M.; Murray, R. W. J. Am. Chem. Soc. 2002, 124, 9310. (b) Lee, D.; Harper, A. S.; DeSimone, J. M.; Murray, R. W. J. Am. Chem. Soc. 2003, 125, 1096.

(4) (a) Geng, L.; Longmire, M. L.; Reed, R. A.; Parcher, J. F.; Barbour C. J.; Murray, R. W. Chem. Mater. 1989, 1, 58. (b) Barbour, C. J.; Parcher, J. F.; Murray, R. W. Anal. Chem. 1991, 63, 604.

(5) Buttry, D. A.; Anson, F. C. J. Am. Chem. Soc. 1983, 105, 685.

(6) (a) Dahms, I. J. Phys. Chem. 1968, 72, 362. (b) Ruff, I.; Friedrich, V. J. J. Phys. Chem. 1971, 75, 3297.

(7) $\delta$ is taken as the equilibrium center-center distance between Co complexes and is calculated from the melt density based on a cubic lattice model.

(8) (a) Sutin, N.; Brunschwig, B. S.; Creutz, C.; Winkler, J. R. Pure Appl. Chem. 1988, 60, 1817. (b) Newton, M. D.; Sutin, N. Annu. Rev. Phys. Chem. 1984, 35, 437.

(9) (a) Marcus, R. A.; Sutin, N. Biochim. Biophys. Acta 1985, 811, 265. (b) Marcus, R. A.; Siddarth, P. In Photoprocesses in Transition Metal Complexes, Biosystems, and Other Molecules; Kochanski, E., Ed.; Kluwer Academic Publishers: Dordrecht, The Netherlands, 1992. (c) Sutin, N. Acc. Chem. Res. 1982, 15, 275. (d) Sutin, N. Prog. Inorg. Chem. 1993, 30, 441.

(10) Pyati, R.; Murray, R. W. J. Am. Chem. Soc. 1996, 118, 1743. 10410 .

(11) Fu, Y.; Cole, A. S.; Swaddle, T. W. J. Am. Chem. Soc. 1999, 121,

(12) (a) Zhang, X.; Leddy, J.; Bard, A. J. J. Am. Chem. Soc. 1985, 107, 3719. (b) Zhang, X.; Yang, H.; Bard, A. J. J. Am. Chem. Soc. 1987, 109, 1916. (c) Oyama, N.; Ohsaka, T.; Ushirogouchi, T. J. Phys. Chem. 1984, 88, 5274. (d) Zhou, H. F.; Dong, S. J. J. Electroanal. Chem. 1997, 425, 55.

(13) No correlation had been seen in an earlier, more limited study. ${ }^{1 \mathrm{c}}$

(14) Ritchie, J. E.; Murray, R. W. J. Phys. Chem. 2001, 105, 1152311528 .

(15) Porat, A.; Crooker, J. C.; Zhang, Y.; LeMest, Y.; Murray, R. W. Anal. Chem. 1997, 69, 5073.

(16) IDA and LDM electrodes were generously donated by O. Niwa of Nippon Telephone and Telegraph (Tokyo, Japan).
(17) Woodard, S. W., design consultant, University of North Carolina at Chapel Hill.

(18) (a) $D_{\text {PHYS }}$ was obtained from the Cottrell Equation, ${ }^{18 b, c} i=$ $\left(n F A D^{1 / 2} C\right) /\left(\pi^{1 / 2} t^{1 / 2}\right)$, where $F$ is the Faraday constant, $A$ is the microelectrode area, ${ }^{18 \mathrm{~d}} \mathrm{D}$ is the diffusion coefficient, and $C$ is the concentration. (b) Bard, A. J.; Faulkner, L. R. Electrochemical Methods; Wiley: New York, 1980; p 143. (c) Cottrell, F. G. Z. Phys. Chem. 1902, 42, 385. (d) The radius of the microelectrode $(15 \mu \mathrm{m})$ was calibrated by voltammetry of ferrocene.

(19) (a) $D_{\mathrm{APP}}$ is obtained from the microdisk equation, $I_{\mathrm{SS}}=$ $4 n F r D_{\mathrm{APP} C}$. ${ }^{19 \mathrm{~b}, \mathrm{c}}$ (b) Wightman, R. M. Anal. Chem. 1981, 53, 1125A. (c) Kovach, P. M.; Lowry, C.; Peters, D. G.; Wightman, R. M. J. Electroanal. Chem. 1985, 185, 285.

(20) MacCallum, J. R.; Vincent, C. A. Polymer Electrolyte Reviews; Elsevier Applied Science: Oxford, U.K., 1987; Vol. 1.

(21) (a) When considering the ratio of $D_{\mathrm{CION}} / D_{\mathrm{E}}$, electronic migration is not significant except for the +2 mol MePEG 350 sample. To correct for this a 1:1 ion pairing relationship between cobalt complex and counterion was assumed in this sample to calculate the reported $D_{\text {CION }}$. In addition, a calculation using Saveant's theory $1 \mathrm{~b}$ showed that electronic migration enhances $k_{\mathrm{EX}}$ by a minor ca. 1.1-fold factor in all the samples. Ionic migration was also calculated to be negligible because the transference numbers $t_{\mathrm{CION}}$ of the counterions were only modestly less than unity. ${ }^{21 \mathrm{c}, \mathrm{d}}$ (b) Andrieux, C. P.; Saveant, J. M. J. Phys. Chem. 1988, 92, 6761. (c) $t_{\mathrm{CION}}=z_{\mathrm{CION}}{ }^{2} D_{\mathrm{CION}} C_{\mathrm{CION}} / \Sigma\left(z_{i}^{2} D_{i} C_{i}\right)$. (d) Bard, A. J.; Faulkner, L. R. Electrochemical Methods: Fundamental and applications; John Wiley \& Sons: New York, 1980; pp 66, 123.

(22) Wang, W.; Lee, D.; Leone, A. M.; Murray, R. W. Manuscript in preparation.

(23) (a) The characteristic parameter, $\psi$, relates the $\Delta E_{\mathrm{PEAK}}$ values to heterogeneous electron-transfer rate constants $\left(k_{\mathrm{HET}}\right)$ through the equation, ${ }^{23 \mathrm{~b}, \mathrm{c}}$ $\Psi=\left(k_{\mathrm{HET}}\left(D_{\mathrm{o}} / D_{\mathrm{r}}\right)^{\alpha / 2}\right) /\left[D_{\mathrm{o}} \pi v(n F / R T)\right]^{1 / 2}$, where $D_{\mathrm{o}}$ and $D_{\mathrm{r}}$ are the selfdiffusion coefficients of the $\mathrm{Co}(\mathrm{III})$ and $\mathrm{Co}(\mathrm{II})$ complexes respectively, ${ }^{23 \mathrm{~d}}$ $\alpha$ is the transfer coefficient (assumed to be 0.5 ), and $v$ is potential sweep rate. Digital simulation (Digisim 2.1) ${ }^{23 \mathrm{e}}$ of a cyclic voltammogram with a simulated $\Delta E_{\mathrm{PEAK}}$ will correspond to a simulated $k_{\mathrm{HET}}$ that can be used to calculate $\psi$ values. In this way, a standard curve of $\psi$ vs $\Delta E_{\mathrm{PEAK}}$ can be created and used to determine an experimental $k_{\mathrm{HET}}$ when $\Delta E_{\mathrm{PEAK}}$ is measured. (b) Nicholson, R. S.; Shain, I. Anal. Chem. 1964, 36, 706. (c) Nicholson, R. S. Anal. Chem. 1965, 37, 1351. (d) $D_{\mathrm{o}}$ and $D_{\mathrm{r}}$ have been shown to be equal according to ref 2b. (e) Bioanalytical Systems, Lafayette, IN.

(24) (a) Weaver, M. J. Chem. Rev. 1992, 92, 463. (b) Fawcett, W. R.; Opallo, M. Angew. Chem., Int. Ed. Engl. 1994, 33, 2131. (c) Zusman, L. D. Chem. Phys. 1980, 49, 295. (d) Calef, D. F.; Wolynes, P. G. J. Phys. Chem. 1983, 87, 3387.

(25) (a) Fawcett, W. R.; Opallo, M. J. Phys. Chem. 1992, 96, 2920. (b) Fawcett, W. R.; Opallo, M. J. Electroanal. Chem. 1993, 349, 273. (c) Fawcett, W. R.; Opallo, M. J. Electroanal. Chem. 1992, 331, 815.

(26) The fraction $\theta$ will be unity if the reaction adiabaticity is strong and there is a small inner-sphere contribution to the activation energy barrier. The dependence of the reaction on solvent is weakened when either of these requirements is not met, causing $\theta$ to decrease in value. ${ }^{24 \mathrm{~b}, 25}$

(27) Marcus, R. A. J. Phys. Chem. B 1998, 102, 10071. 